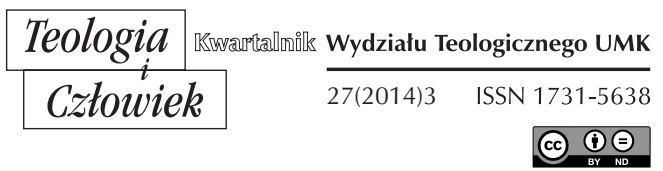

ARLETA CHOJNIAK*

POZNAŃ

\title{
DUCHOWOŚĆ JEDNOSTKI A KOMUNIKACJA MIĘDZYKULTUROWA
}

DOI: http://dx.doi.org/10.12775/TiCz.2014.037

Problematyka niniejszego artykułu z jednej strony reprezentuje interdyscyplinarną refleksję nad komunikacją międzykulturową, a z drugiej jest próbą odczytania i rozważenia tego fenomenu w kontekście ludzkiej duchowości. Dla osiągnięcia tego celu wybrałam współczesną teorię komunikacji międzykulturowej autorstwa Young Yun Kim i Brenta D. Rubena, koncentrującą się na ujęciu komunikacji przez pryzmat procesów i zdarzeń zachodzących w jednostce. Perspektywa jednostkowa nakreślona w tej koncepcji, a przy tym szeroko odwołująca się do ustaleń psychologicznych, pozwala moim zdaniem na rozważenie jej związków z psychologiczną kategorią duchowości.

W celu rozpatrzenia tytułowej relacji powołam się na definicję kultury autorstwa amerykańskiego antropologa Clifforda Geertza, który w eseju Religia jako system kultury proponuje następujące określenie: „pojęcie kultury odnosi się do ucieleśnionego w symbolach, przekazywanego z pokolenia na pokolenie wzoru znaczeń, systemu odziedziczonych

* Arleta Chojniak - dr nauk humanistycznych w zakresie psychologii, adiunkt w Zakładzie Historii i Metodologii Nauk o Kulturze w Instytucie Kulturoznawstwa UAM w Poznaniu. 
wyobrażeń wyrażonych w symbolicznych formach, dzięki którym ludzie przekazują, utrwalają i rozwijają swoją wiedzę o życiu i swój doń stosunek"1. $^{\prime 1}$ Spójna z tym ujęciem pozostaje też definicja Warda Hunta Goodenougha wskazująca, że „kultura nie jest zjawiskiem materialnym, nie stanowią jej rzeczy, ludzie, zachowania czy przeżycia emocjonalne. Jest to raczej organizacja tych zjawisk. Stanowią ją formy rzeczy w umysłach ludzi - modele ich percypowania, inaczej - interpretowania ich" ${ }^{\prime 2}{ }$, a także definicja Jerzego Kmity, który przez kulturę rozumie zbiór przekonań normatywnych i dyrektywalnych, wyznaczający odpowiednie działania i cechujący się powszechnym respektowaniem w danej społeczności ${ }^{3}$.

W przytoczonych ujęciach wspólne jest traktowanie kultury jako rzeczywistości mentalnej determinującej odpowiednie działania i wytwory tych działań. Jednostki, poprzez system kulturowy, jakim jest język, nie tylko uczą się nazywać i kategoryzować własne doświadczenie, lecz także -- zgodnie z hipotezą Edwarda Sapira i Benjamina Lee Whorfa - przejmują cały układ przekonań wyznaczających, co ma być percypowane ${ }^{4}$.

$\mathrm{W}$ związku z zaprezentowanym rozumieniem kultury duchowość indywidualną definiuję jako formę doświadczenia wewnętrznego określoną w znacznym stopniu przez kulturę symboliczną wspólnoty, w której jednostka uczestniczy. Oznacza to, że kultura symboliczna danej społeczności, stanowiąc wspólną wiedzę, umożliwia uczenie się doświadczeń duchowych. Pomaga zatem nazwać, rozpoznać i zaklasyfikować dane przeżycie jako przynależne do kategorii duchowości. Jednak owa wiedza wspólnoty ani nie jest równoznaczna z samym doświadczeniem duchowym, ani też go nie tworzy.

Konstytutywną cechę duchowości upatruję w zdolności do autotranscendencji. Przyjmując takie rozumienie fenomenu duchowości, odwołuję się do idei austriackiego lekarza i psychoterapeuty Victora Emila Frankla, mającej swe filozoficzne źródła zwłaszcza w koncepcjach Franza Brentany, Edmunda Husserla i Maxa Schelera. W kontekście tej tradycji filozoficznej przejawem autotranscendencji jest intencjonalne nakierowanie

${ }^{1}$ C. Geertz, Religia jako system kulturowy, tłum. E. Mokrzycki, w: Racjonalność i styl myślenia, red. E. Mokrzycki, Warszawa 1992, s. 500.

${ }^{2}$ W. H. Goodenough, Cultural Anthropology and Linguistic, w: Language in Culture and Society, red. D. Hymes, New York 1964, za: G. Banaszak, J. Kmita, Społeczno-regulacyjna koncepcja kultury, Warszawa 1991, s. 48.

${ }^{3}$ Zob. np. G. Banaszak, J. Kmita, dz. cyt., s. 44.

${ }^{4}$ Zob. np. E. Sapir, Kultura, język, osobowość. Wybrane eseje, tłum. B. Stanosz, R. Zimand, Warszawa 1978. 
się osoby na sferę sensów i wartości oraz zgodne i konsekwentne działanie na niej oparte. Dzięki tej zdolności osoba ma możliwość „przekroczenia" - transgresji i zmiany dotychczasowego (w większości przypadków niesatysfakcjonującego bądź niezdrowego) sposobu funkcjonowania.

Należy jednak stwierdzić, że powyższe rozumienie fenomenu duchowości nie jest do końca zbieżne $\mathrm{z}$ powszechnie przyjmowanym przez psychologów. Ze względu na dominujący w psychologii paradygmat badawczy, odwołujący się do metodologii wprowadzonej przez behawiorystów, w badaniach nad duchowością podkreśla się jej funkcjonalne (przedmiotowe) aspekty, kosztem charakterystyk podmiotowych. Te ostatnie wymagałyby zastosowania metod opartych na "rozumieniu”, czyli typowych dla nauk humanistycznych. Orientacja przyrodoznawcza psychologii skutkuje między innymi tym, że utożsamia się ze sobą zjawiska, które pod względem treści są odmienne. Wyrazem tej tendencji jest szerokie rozumienie autotranscendencji występujące $\mathrm{w}$ psychologii (tylko w części zgodne z przyjętym przeze mnie): akty mogą być ukierunkowane na obiekty zewnętrzne względem jednostki, takie jak: Bóg, siła wyższa, drugi człowiek, uniwersum. Mogą także zachodzić w obrębie systemu ja - dotyczą wtedy procesu samorealizacji, samodoskonalenia, rozwoju osobistego itp. ${ }^{5}$ Widać zatem, że psychologiczna kategoria duchowości nie obejmuje wyłącznie intencjonalnej relacji osoby do sfery sacrum. Przez pojęcie duchowości rozumie się też różnego rodzaju transgresje, polegające na przekraczaniu doczesnych uwarunkowań człowieka. Inny trend, silnie zaznaczający się $\mathrm{w}$ badaniach psychologicznych, przejawia się $w$ naturalizowaniu duchowości, czyli ujmowaniu jej jako wrodzonej zdolności gatunku ludzkiego czy jeszcze szerzej - całej materii (np. na gruncie psychologii - koncepcja inteligencji duchowej Danah Zohar i Iana Marshalla czy też badania $\mathrm{w}$ ramach tzw. neuroteologii $\left.{ }^{6}\right)$.

Prezentowana w niniejszym artykule koncepcja autorstwa Kim i Rubena ani nie analizuje bezpośrednio fenomenu ludzkiej duchowości, ani też nie rozważa szczegółowo kwestii jej roli w komunikacji międzykulturowej. Badaczy interesuje raczej ujęcie komunikacji $\mathrm{w}$ aspekcie procesów zachodzących w jednostce. Jednakże, rozważając owe procesy, koncentrują się na przemianach, jakie zachodzą $\mathrm{w}$ indywiduum podczas

${ }^{5}$ I. Heszen, E. Gruszczyńska, Wymiar duchowy człowieka, jego znaczenie w psychologii zdrowia $i$ jego pomiar, „Przegląd Psychologiczny” 24 (2004), nr 1, s. 15-31.

${ }^{6}$ D. Zohar, I. Marshall, Inteligencja duchowa. Najwyższa $z$ inteligencji, tłum. P. Turski, Poznań 2001. 
długotrwałej interakcji międzykulturowej, oraz na ukazaniu ich konsekwencji dla rozwoju osobowości. Moim zdaniem charakter tych przemian odpowiada zjawiskom, które współczesna refleksja psychologiczna włącza w zakres doświadczeń duchowych. Tę opinię postaram się poniżej uzasadnić.

Proponowane przez Kim i Rubena ujęcie ma stanowić próbę integracji dwóch - dotychczas konkurencyjnych - perspektyw teoretycznych ${ }^{7}$. W ramach pierwszej perspektywy badania koncentrowały się na negatywnych czynnikach związanych z kontaktem międzykulturowym. Ogół takich doświadczeń określono jako szok kulturowy. Drugie podejście reprezentowane głównie przez Petera Adlera odrzuca ujęcie szoku kulturowego jako doświadczenia wyłącznie negatywnego. Według tego badacza szok kulturowy, uruchamiając mechanizmy zmiany, prowadzi do rozwoju osobowości oraz głębszego samorozumienia. Rozwój jednostki wchodzącej w interakcję międzykulturową przebiega jego zdaniem stadialnie. Adler wyróżnił pięć faz rozwojowych: 1) fazę kontaktu, 2) dezintegracji, 3) reintegracji 4) stadium autonomii, 5) stadium niezależności. Autorzy, uwzględniając oba podejścia, rezygnują jednocześnie z ujęcia stadialnego. $\mathrm{W}$ ramach swojej teorii widzą raczej potrzebę podkreślenia ciągłości oraz cykliczności procesu transformacji, przez który jednostka przechodzi.

Zgodnie z reprezentowanym przez nich stanowiskiem holizmu, widocznym w odwoływaniu się do ogólnej teorii systemów, indywiduum traktują jako otwarty system komunikacyjny powiązany informacyjnie ze swoim środowiskiem. Przyjmują założenie, że człowiek jest zasadniczo układem homeostatycznym. Bodźce płynące ze środowiska mogą oddziaływać na niego w różny sposób. Niektóre z nich wytrącają jednostkę ze stanu równowagi poznawczej. Doświadcza ona wtedy napięcia i stresu, które stanowią całościową reakcję organizmu pojawiającą się, gdy zasoby i kompetencje jednostki są w jakiś sposób nieadekwatne do sytuacji bodźcowej. Najczęściej uruchamiają się w pierwszej kolejności różne mechanizmy obronne, np. takie jak: zaprzeczanie, izolacja, unikanie, dzięki którym osoby próbują uniknąć antycypowanego lub rzeczywistego stanu

${ }^{7}$ Choć w zasadzie stanowi modyfikację drugiego podejścia - reprezentowanego przez Petera Adlera.

${ }^{8}$ Y. Y. Kim, B. D. Ruben, Intercultural Transformation. A Systems Theory, w: Theories in Intercultural Communication, red. Y. Y. Kim, W. B. Gudykunst, Newbury Park-Beverly Hills-London-New Delhi 1988, s. 304. 
szeroko rozumianego zagrożenia. Manifestują się one często $\mathrm{w}$ formie wrogości, cynizmu czy kompulsywnego altruizmu9 .

Jeśli wymagania płynące ze strony otoczenia nadal pozostają aktywne, a mechanizmy obronne są nieskuteczne, to - zdaniem badaczy - w większości przypadków jednostki decydują się na podjęcie szeregu działań mających na celu przekształcenie wewnętrznego i zewnętrznego środowiska. Taka możliwość zachodzi dzięki unikalnej ludzkiej umiejętności, jaką jest zdolność do ciągłych adaptacji i twórczych transformacji. Jednostki uczą się postrzegać sytuację w nowym kontekście, tworzyć nową siatkę znaczeń, patrzeć „nowymi oczami”"10. W konsekwencji potrafią odzyskać utraconą równowagę. Wewnętrzna harmonia nie jest jednak stanem osiągniętym raz na zawsze. Trwa aż do momentu ponownej konfrontacji z nieoczekiwanymi i nieznanymi wyzwaniami. Zdaniem Kim i Rubena ludzie nieustannie stoją w obliczu nowych doświadczeń, w odniesieniu do których nie mają wystarczających narzędzi poznawczych, emocjonalnych i behawioralnych. Cyklicznie przechodzą przez proces określany jako dynamika: stres - adaptacja - wzrost. Nowe i nieoczekiwane bodźce, burząc wewnętrzną harmonię, uruchamiają jednocześnie motywację do jej odzyskania. Przyczyniają się w ten sposób do reorganizacji poznawczej, emocjonalnej i behawioralnej. W konsekwencji jednostki uczą się nowych sposobów funkcjonowania, poszerzają zasób swoich kompetencji społecznych i kulturowych pozwalających na lepszą adaptację do nowej sytuacji, a co za tym idzie rozwijają własną osobowość.

Zdaniem autorów nie można doświadczyć korzyści płynących ze wzrostu i rozwoju osobowości bez towarzyszących im negatywnych przeżyć. Związek stresu i wewnętrznego wzrostu jest wręcz relacją konieczną. Parafrazując ich słowa, można powiedzieć: jeden czynnik nie zachodzi bez drugiego, co więcej - zachodzi właśnie z powodu drugiego. Jako przykład ukazujący powiązanie zdarzeń kryzysowych z rozwojem osobistym wskazują sytuację komunikacji międzykulturowej. Zakładają przy tym, że postulowane przez nich zależności ujawniają się najsilniej w sytuacji długotrwałego kontaktu. Komunikację ujmują jako proces dekodowania oraz kodowania informacji niezbędnej do funkcjonowania $\mathrm{w}$ danym środowisku. Natomiast komunikacja międzykulturo-

9 Zob. Y. Y. Kim, Cross-cultural adaptation. An integrative theory, w: Intercultural communication theory, red. R. L. Wiseman, Thousand Oaks 1995, s. 177.

${ }_{10}$ Y. Y. Kim, B. D. Ruben, dz. cyt., s. 308. 
wa zachodzi w sytuacji, gdy osoby wchodzące $\mathrm{w}$ interakcje przejawiają odmienne, pod względem kulturowym, wzorce komunikacyjne.

Stresogenność spotkania międzykulturowego wynika przede wszystkim z poziomu, na którym zachodzi reorganizacja. $\mathrm{W}$ trakcie enkulturacji osoby poznają reguły kategoryzacji świata, które stanowią produkt działalności komunikacyjnej innych ludzi. Ten „kulturowy imprinting" stanowi głęboko nieświadome wyposażenie ludzkiego umysłu. Jako taki odpowiada za ograniczoną zdolność do doświadczania fenomenów spoza własnej kultury. Pozostaje w dużym stopniu nierozpoznaną i niekwestionowalną strukturą aż do czasu spotkania z ludźmi o odmiennych wzorcach komunikacyjnych. Szok kulturowy jest tym większy, im bardziej różnią się kultury reprezentowane przez osoby uczestniczące w spotkaniu. Zakwestionowanie struktury mentalnej nabytej w dzieciństwie jest odbierane jako stan wewnętrznego napięcia i konfliktu. Jednostki zostają zmuszone do przynajmniej czasowej modyfikacji starych sposobów funkcjonowania i akomodacji nowych. Te psychologiczne przekształcenia prowadzą do okresowej dezintegracji osobowości, skutkującej w ekstremalnych przypadkach załamaniem psychicznym.

Pomimo tego Kim i Ruben twierdzą, że czasowa dezintegracja stanowi niezbędną podstawę dalszego rozwoju osobowości. Choć stres odpowiada za przeżywanie cierpienia, frustracji i niepokoju, to równocześnie pobudza do twórczości, uczenia się oraz poszerzenia kompeten$\mathrm{cji}^{11}$. Rozwijając tę ideę, powołują się explicite na koncepcję dezintegracji pozytywnej sformułowaną przez polskiego psychologa Kazimierza Dąbrowskiego. Dla tego uczonego rozwój jest wielopoziomowym procesem, którego sekwencje zostają wyznaczone przez okresy wewnętrznych konfliktów, prowadzące do mniej lub bardziej głębokiej dezintegracji. Dezintegracja - jako stadium konieczne - poprzedza stworzenie nowej, $\mathrm{w}$ pełni podmiotowej struktury. Atrybutami podmiotu na najwyższym stopniu rozwoju są między innymi odpowiedzialność, autonomia, samodoskonalenie oraz empatia $\mathrm{w}$ odniesieniu do innych bytów. Miłość jest przejawiana "równie silnie w stanach medytacji i kontemplacji, jak i w warunkach życia codziennego"12. Dąbrowski zakładał, że rozwój dotyczy całej osobowości, w tym także wymiaru duchowego opartego na realizacji uniwersalnych według niego wartości ${ }^{13}$. Orientacja na sferę

11 Tamże, s. 311.

${ }^{12}$ K. Dąbrowski, Funkcje i struktura emocjonalna osobowości, Lublin 1984, s. 68.

${ }^{13}$ Zob. np. tamże, s. 19. 
wartości odpowiada za ukierunkowanie działań transgresyjnych, które $\mathrm{w}$ innym przypadku stanowiłyby zbiór chaotycznych przemian ${ }^{14}$.

Powyższe twierdzenie, choć niewyrażone wprost przez Kim i Rubena, znajduje odzwierciedlenie w ujęciu konsekwencji uczestnictwa w komunikacji międzykulturowej dla osobowości człowieka. Jednym z rezultatów tych doświadczeń jest wzrost w zakresie kompetencji międzykulturowej, prowadzący do zmian w tożsamości. Tożsamość wielokulturową charakteryzują za Adlerem jako opierającą się „nie na «przynależności», która implikuje posiadanie lub bycie posiadanym przez kulturę, lecz na stylu samo-świadomości zdolnym do negocjowania ciągle nowych formacji rzeczywistości"15. Innymi słowy, osoba o tożsamości wielokulturowej żyje „na granicy”. Nie jest już w pełni częścią swej własnej kultury ani też nie jest poza nią.

Drugą konsekwencję upatrują w ukonstytuowaniu się specyficznej struktury poznawczej, manifestującej się pogłębionym rozumieniem ludzkich uwarunkowań i akceptacją różnic kulturowych. Według nich typ przemian poznawczych stanowiących wynik interakcji międzykulturowych ma podobne relacje strukturalne jak w przypadku odkryć naukowych czy oświecenia religijnego. Następuje przejście od etnocentrycznej i dualistycznej percepcji do niedualistycznej, metakontekstualnej ${ }^{16}$.

Poszerzonej i pogłębionej perspektywie poznawczej może towarzyszyć wzrost kompetencji emocjonalnych i behawioralnych, przejawiający się m.in. w większej otwartości, wrażliwości międzykulturowej, empatii oraz odporności psychicznej ${ }^{17}$. Co więcej, dynamika ukierunkowana na wewnętrzną harmonię skutkuje kongruencją - zgodnością i integracją procesów kognitywnych, emocjonalnych i behawioralnych. Jak piszą badacze, gdy rozpada się "stara osoba”, wtedy wiedza międzykulturowa, postawy i umiejętności behawioralne tworzą "nową jednostkę" na wyższym poziomie integracji.

Przedstawiona charakterystyka przemian zachodzących $\mathrm{w}$ osobie pozwala moim zdaniem na twierdzenie, że wykazują one szereg zbieżności z psychologicznym rozumieniem duchowości. Podobieństwa są 1993, s. 97.

${ }^{14}$ Zob. L. Korporowicz, Tworzenie sensu. Jezyk - kultura - komunikacja, Warszawa

${ }^{15}$ P. Adler, Beyond Cultural Identity: Reflections on Multiculturalism, http://www. mediate.com/articles/adler3.cfm (dostęp 31.05.2014).

16 Zob. Y. Y. Kim, B. D. Ruben, dz. cyt., s. 314.

17 Zob. Y. Y. Kim, dz. cyt., s. 186-187. 
widoczne szczególnie w traktowaniu działań jednostek uczestniczących w sytuacji komunikacji międzykulturowej jako transgresji prowadzących do znacznego rozwoju osobowości, zdobycia większej samoświadomości i umiejętności głębszego rozumienia innych ludzi. Transcendowanie poza dotychczasowe sposoby funkcjonowania ma zdaniem badaczy umożliwić jednostkom większą autonomię wobec czynników determinujących ich działania, a tym samym prowadzi do poszerzenia sfery podmiotowości.

Zasadnicza odmienność w stosunku do większości ujęć duchowości rozwiniętych na gruncie psychologii jest związana z poziomem zmian, jakim podlegają osoby. W świetle koncepcji Kim i Rubena, przemiana wiąże się z systemem znaczeń i symboli strukturyzujących umysł jednostki i porządkujących jej doświadczenie rzeczywistości. Dzięki spotkaniu z osobami reprezentującymi inną kulturę jednostki uświadamiają sobie własne kody kulturowe - $\mathrm{w}$ tym określające pojmowanie duchowości. Choć zakwestionowanie tych wzorców może być doświadczeniem dezintegrującym, to zdaniem badaczy $\mathrm{w}$ większości przypadków ma pozytywne konsekwencje. Prowadzi to do wniosku, że twórcy omawianej teorii utożsamiają wzrost kompetencji kulturowych, stanowiący rezultat doświadczenia komunikacji międzykulturowej, z postępem. Optują zatem za aksjologicznym pojęciem rozwoju jako ciągiem zmian "na lepsze”, przybliżających do ideału, który w ich koncepcji został zarysowany raczej ogólnikowo.

Streszczenie. Celem artykułu jest analiza - w kontekście duchowości indywidualnej - koncepcji komunikacji międzykulturowej zaproponowanej przez Young Yun Kim i Brenta Rubena. W ramach tej teorii komunikacja międzykulturowa jest postrzegana jako proces cyklicznych przemian, który umożliwia jednostkom transcendowanie poza kulturowe wzorce myślenia, odczuwania i zachowania w kierunku szerszych kompetencji międzykulturowych i wyższego poziomu rozwoju osobowości. Moim zdaniem typ przemian zachodzący podczas interakcji międzykulturowej, obserwowany przez autorów, jest powiązany z psychologiczną kategorią duchowości.

Słowa kluczowe: duchowość; komunikacja międzykulturowa; zmiana; transcendencja.

Summary: The Spirituality of an individual and intercultural communication. The aim of this paper is to analyze - in the perspective of individual spirituality - the conception of intercultural communication, proposed by Young Yun Kim and Brent Ruben. In this theory intercultural communication is presented as a process of cyclic changes which enables the individuals to transcend their cultural patterns 
of thinking, feeling and behaving so that the increased intercultural competence and a higher level of personal development is achieved. In my opinion the type of changes which take place in the intercultural interactions, observed by the authors, is connected with psychological cathegory of spirituality.

Keywords: spirituality; intercultural communication; change; transcendence. 
